Punnyasoma, J.A.G., Jayasena, H.S. and Tennakoon, T.M.M.P., 2019. Use of BIM solutions to facilitate value management. In: Sandanayake, Y.G., Gunatilake, S. and Waidyasekara, A. (eds). Proceedings of the $8^{\text {th }}$ World Construction Symposium, Colombo, Sri Lanka, 8-10 November 2019, pp. 598-607. DOI: doi.org/10.31705/WCS.2019.59. Available at: https://2019.ciobwcs.com/papers

\title{
USE OF BIM SOLUTIONS TO FACILITATE VALUE MANAGEMENT
}

\author{
J.A.G. Punnyasoma ${ }^{1}$, H.S. Jayasena ${ }^{2}$ and T.M.M.P. Tennakoon ${ }^{3}$
}

\begin{abstract}
Value management is a practice of generating innovate alternative ideas to improve the value of a project where the goals are to achieve a more efficient design, identify alternative methods of constructions, identify and omit unnecessary cost components and managing the whole life cycle cost of the project. The aim of this research is to find the ability of BIM in incrementing efficiencies of value management process within Sri Lankan context. Case study method was used. The selected case is considered as a benchmark on sustainable buildings of the Sri Lankan construction sector. The sevenstep value management approach following the Client's requirements identified for the project was first documented. BIM tools and features applicable for each step of value management process was then identified followed by clarification of the effect and the efficiency of each step of the process. A value management plan was built up with the use of BIM solutions for the studied case. BIM was identified as one of the most efficient and accurate media to extract the basic and detailed project information for value management process. Simulating, comparing and contrasting the information of rainfall, wind flow, daylight, cost, designs and resources for the implementation of passive cooling systems, lighting control systems, green roofing and alternatives to reduce grey energy was effectively analysed in this paper using BIM solutions.
\end{abstract}

Keywords: Building Information Modelling; Sustainable Buildings; Value Management.

\section{INTRODUCTION}

During the recent 10 years, Sri Lanka has shown a steady growth in construction industry which has emerged as an important sector in the economy. Sri Lanka's post-conflict growth has been fuelled by construction, which increased its share of GDP from 6.6 percent in 2009 to 8.7 percent in 2013 (Davies, 2014); and it still remains around 7 percent (Central Bank of Sri Lanka, 2019). The economic challenges in the sector continue to demand best value for every investment made without reducing the quality yet balancing the cost at an optimal level. Hence, value creating initiatives such as value management can be identified as vital procedure that should be followed in any building construction project.

Value management has been defined as a team orientated, multi-disciplinary wellstructured analytical process which aids in systematic analysis of function to obtain the maximum value through the design and construction process to fulfil the client's exact needs (Jaapar et al., 2016). The value management procedure commences from the

\footnotetext{
${ }^{1}$ Department of Building Economics, University of Moratuwa, Sri Lanka, punnyasomag@gmail.com

${ }^{2}$ Department of Building Economics, University of Moratuwa, Sri Lanka, suranga@uom.lk

${ }^{3}$ Department of Building Economics, University of Moratuwa, Sri Lanka, ra-maheshi@uom.lk
} 
planning stage and should be followed through the whole life cycle of the project to reduce cost without reducing the quality and functional efficiency of a project (Lin and Shen, 2007). A better value is gained though a balanced cost which is neither too less nor too high (Thiry, 2002). In order to gain a better output, the key factors of value management should be identified to allocate the limited resources (Shen and Liu, 2003). The possibilities to use novel information solutions to simplify the tasks involved in value management planning has been considered in the construction industry from some time.

Building Information Modelling (BIM) is such an information solution supported by digital machine-readable documentation about a building, its performance, planning, construction, and its operation and maintenance. BIM characterize the built environment of the building on a virtual platform (Succar, 2010). BIM has the ability to capture, manipulate and arrange large amount of data related to the built environment. It digitally represents the physical and functional characteristics of a building (Arayici et al., 2012).

Even though several researches have already been done on value management and applications of BIM for various aspects of building construction there is a research gap remaining to comprehend the ability of BIM in incrementing efficiencies of value management process within Sri Lankan context. Better information will help positive adoption of BIM in Sri Lankan industry which is yet to find its benefits (Rogers et al., 2015). To bridge this gap, an in-depth literature review was carried out which was followed by a case study from Sri Lanka.

\section{VALUE MANAGEMENT}

The term 'Value' implies different meanings for different disciplines. Value is defined as the ratio between the desired performance of a product and the overall production cost (Rangelova and Traykova, 2014). Value achieved by balancing the three cores of a product cost, time and quality (Ellis et al., 2005). Subsequently, value management practice approaches problem solving with a wider resolution than many other problemsolving techniques and it is a problem solving tool which includes a number of qualitatively different components. It is a commonly used management tool where the main focus is on innovating alternatives to improve value of a product (Spaulding et al., 2005). The definitive intention of value management is to deliver the maximum value without any cost cutting strategy (Perera et al., 2011).

Value management has become a popular tool used within the modern construction industry. It is a tool which is used by a design team to maximize the value of a project in respective to the clients' requirement. Furthermore, value management becomes a wider theory in construction technology, which focus on improving the value delivered to the customer through the entire life cycle of the building (Kelly et al., 2016). In construction industry, the concept of value management often focuses on the constraints such as cost, function, quality and durability (Salvatierra-Garrido and Pasquire, 2011). Function, time, quality and cost of every single activity and element that is includes in the construction process required to be identified, determined and estimated earlier. Thus, value management ensures that the construction process generates the value desired by the client. 


\subsection{Methodology of Value Management Process}

In common practice, a team consisted of professionals lead by a value management expertise along with a facilitator conducts the value management studies in the form of workshops (Luo et al., 2010). The value management team must be consisted of expertise who are aware about the entire life cycle, the required needs and functions of the particular project (Perera et al., 2011). The value management job plan, facilitates to take a step-by-step approach have the following four basic steps (Ashworth and Hogg, 2000; Kelly et al., 2016):

4. Issues analysis - accumulating information (including information on values to be used in decision-making).

5. Function analysis - prioritizing information (normally as a set of functional requirements/objectives).

6. Creativity - creative thinking (to generate options and packages of options).

7. Evaluation - prioritizing options (making decisions which balance use of resources and functionality in meeting objectives).

In Table 1 the commonly used phases of value management which are extended from the main four phases has been summarised.

Table 1: Steps of value management process

\begin{tabular}{ll}
\hline \multicolumn{1}{c}{ Phase } & \multicolumn{1}{c}{ Objectives } \\
\hline $\begin{array}{l}\text { Pre study } \\
\text { phase }\end{array}$ & - Identify problem statement and preparation for the value study \\
\hline $\begin{array}{l}\text { Information } \\
\text { phase }\end{array}$ & - Establish Value Management study objectives \\
& - Absorb and analyse information required to carry out the study, including, \\
& - Client and end-user requirements by the value management team \\
\hline $\begin{array}{l}\text { Creative } \\
\text { phase }\end{array}$ & - Develop creative alternative solutions and ideas generation through \\
& - Drainstorming, Gordon technique or synoptic technique \\
\hline $\begin{array}{l}\text { Evaluation } \\
\text { phase }\end{array}$ & - Evaluate ideas generated, analysis and ranking of solutions \\
\hline $\begin{array}{l}\text { Development } \\
\text { phase }\end{array}$ & - Determine the most suitable alternatives for the decision-maker \\
\hline Presentation & - Reconomical validity \\
phase & - Provide final recommendation to the client \\
\hline Source: Adaplement the recommendations.
\end{tabular}

Source: Adapted from Dallas (2006) and Rangelova and Traykova (2014)

\section{BIM FOR VALUE MANAGEMENT}

Building Information Modelling is one of the most important inventions in engineering, architecture and construction in latest periods. Eastman et al. (2011) elaborated BIM as "a new approach to planning, design and construction, in which digital representation of the building process is used to facilitate the exchange and interoperability of information in digital format". Building Information Modelling has attracted many initiatives around 
the world since it is an efficient time saving technological solution. In the architectural design areas, BIM oriented high performing building designing is increasingly being used and allows professionals to efficiently generate and modify building models (Welle et al., 2011). According to Pikas et al. (2013) there are three main factors which affects the adoption of BIM in all construction projects.

1. The technological scopes which embraces the interaction among applications, compatibility of software, monitoring and controlling the quality and progress of construction, design clash detection and visualization of BIM standard and protocols.

2. The organizational dimension which includes BIM professionals, BIM vendors, professional trainings of BIM technologies, and support of senior management and clients. The compatibility of all these specialists affects the level and quality of implementation of BIM in a construction project.

3. The attitude factor which includes interest in learning BIM, BIM awareness, willingness to use BIM, perceived cost of BIM technology and platform and willingness to facilitate the implementation of BIM in a building project.

Consequently, Saieg et.al (2018) has highlighted that BIM based sustainability analysing tends achieve a significant time and cost savings in contrast to traditional design methods. Further, the ways in which BIM-based processes to facilitate sustainable design with high value, have been listed that includes promoting the selection of sustainable materials, reducing material consumption, and increasing the use of recycled materials. In order to identify the influence from BIM applications for VM the following research methodology is followed.

\section{RESEARCH METHODOLOGY}

Since the research scope is limited to Sri Lankan context, a case study approach was used to conduct the research. Furthermore, the research consists of how and why questions, the strategies available when conducting a case study facilitates to explore the questions in a more in-depth nature.

The selected case was the value engineering process of a sustainable factory building construction. The study regarding the case was carried out in two parallel phases. The first phase was to identify the value management process for the project. Semi structured interviews were conducted to identify the Client's requirements. The value criteria of the project were confirmed through analysing the Client's requirements. Then a document review with the assistance of the design team members. The phase two was specifically focused on the ability to apply BIM and BIM tools for each step of the value management process. The practical application of BIM solutions was comprehended through developed models and the experience of the project team.

\section{DATA COLLECTION AND ANALYSIS}

The necessary details regarding the project which are required to enhance the value of the project were surveyed and the decision for value enhancement were taken by the Client and the design team during the design and planning stages. 


\subsection{BIM Solutions for VAlue Management of the Selected CaSe}

In the selected case, the Client's requirement was to obtain a sustainable and eco-friendly building as the final product. An in depth analysis of the general information of the case is presented in Table 2 in Section 5.1.2. The selected case was well- known example of effective value management implementations. Therefore, an emphasis was given to analyse the use of BIM related solution for the success of the value management process of the project.

\subsubsection{Pre-Study Phase}

During the pre-study phase the problem statement was identified for the preparation for the value study. Under the problem statement three aspects were answered regarding the project.

- Strategic brief

- Project brief

- Project goal

A briefing process was done prior to the design stage. According to Figure 1, several requirements were emphasized above others for the selected case where the Client's requirements were identified and short-listed.

\begin{tabular}{l}
\hline A - Capital Cost \\
B - Operational and Maintenance Cost \\
C - Project Duration \\
D - Sustainability \\
E - Internal Comfort \\
\hline G - Esteem
\end{tabular}

Figure 1: Value management study objectives

Capital cost and operation \& maintenance cost were the major concerns of the client whereas the esteem and aesthetic appearance were not prioritized since the project is a construction of a factory building. The value management process was built up depending on those factors identified. However, use of BIM at this phase was limited to paper based exhaustive list of client requirements in the selected case, which is similar to Employer's Information Requirement (EIR) documents but with a special focus on value management.

\subsubsection{Information Phase}

In the information phase, the necessary information for the value management study was gathered and a sample of the collected information is given in Table 2.

The information that were collected was consisted of project details including identification of functions of all the elements of the project, client and end-user requirements and finalizing the value management objectives. During the information phase, the Client's requirements processed through a 'Client Value Matrix' and identify the priority level for each requirement. 
Table 2: Main information collected

\begin{tabular}{lll}
\hline \multicolumn{1}{c}{ Site Details } & Basic Building Details & \multicolumn{1}{c}{ Key Cost Details } \\
\hline - Location - Thulhiriya, & - Construction period & - Target construction cost - USD \\
Sri Lanka & - September 2007 to & 2.66 million $\left(338.50 \mathrm{USD} / \mathrm{m}^{2}\right)$ \\
- Climate - Tropical, & April 2008 & - Construction cost of typical \\
Humid & - Building type - & factories in Sri Lanka - 308 \\
- Terrain - Rolling, & clothing factory & USD $/ \mathrm{m}^{2}$ \\
Moderately sloped & - Maximum number & - Target annual operating cost - 0.4 \\
- Area - 3.32 hectares & of occupants - 1,300 & USD $/ \mathrm{m}^{2}$ \\
- Parking - 10 spaces & & - Annual operating cost of \\
for vehicles and 25 for & & comparable factories in Sri Lanka \\
bicycles & & $-1.61 \mathrm{USD} / \mathrm{m}^{2}$ \\
\hline
\end{tabular}

\subsubsection{Creative Phase}

During the creative phase all the creative ideas regarding the project is produced and captured by the value management team. Therefore, specifically for this project during the creative phase, the design ideas were built up by the design team with the client's requirements taken into consideration. During the brainstorming session, new ideas that will meet the Client's requirements were generated. The value management proposal had the first five requirements in the Client's priority list as the focus.

1. High Sustainability

2. Less Project Duration

3. High Internal Comfort

4. Low Capital Cost

5. Low Operation and Maintenance Cost

In the selected case at Thulhiriya experts in civil engineering and architecture, sustainable development, design teams, mechanical engineers, electrical engineers, and facility managers were presented at creative phase to provide ideas for value management proposals. According to the respondents, use of BIM solutions were limited at this stage and only paper-based notes were taken down for further discussion.

\subsubsection{Evaluation Phase}

For the basic evaluation all the ideas generated during brainstorming session were checked to confirm the Client's requirements that each of the ideas fulfil. According to the results obtained, some design concepts met the key requirements. For some of the design concepts, Cost Benefit Analysis (CBA) and Whole Life Cycle Costing (WLCC) were carried out during this phase. BIM as an information solution work as a platform to store the data required for a project. Stored data combined along with the analytical ability of BIM supported in evaluating each idea generated during the brainstorming session in terms of cost, time and benefits and compare each of them to verify what design ideas have the highest cost benefits and lowest life cycle costing. For WLCC process BIM tools are required for calculations and analyzing. The following tools were identified for WLCC calculation.

\section{$\underline{\text { Solibri Model Checker (SMC) Ver. } 8}$}

As a model-checking tool SMC has aided in verification the quality of BIM models produced by the architect/engineer following a specific set of rules. The functions 
consisted of quality checks to BIM models, including visualization, navigation and presentations compilation. SMC has supported test and control of the quality and accuracy of BIM models for various uses such as energy analysis, information take off, and spatial coordination.

\section{Autodesk Quantity Take-Off (QTO)}

Autodesk QTO was identified as a separate cost-estimating tool developed by Revit, to assist estimators and surveyors in quantifications and cost estimates through gathering and coordinating of accurate design information from both 3D BIM and traditional 2D environment.

\section{Exactal CostX Estimating Software}

Cost $\mathrm{X}$ as an estimating tool for BIM based cost management by enabling full integration of $2 \mathrm{D}$ and $3 \mathrm{D}$ digital design data with cost estimates. CostX capture and extract BIM information of object properties, dimensions and descriptions all in a single platform, including electronic measurements, spreadsheet calculations and estimates (Day, 2008; Exactal, 2010) enabling calculation of WLCC easier.

\subsubsection{Development Phase}

In the development phase, the design ideas that were generated during the creative phase and filtered during the evaluation phase were established further. In the Table 3 the innovative ideas were elaborated which were developed by considering the Client's requirements. Furthermore, Table 3 also provides a summarization of the BIM tools that are available for use to succeed each of the value management initiatives suggested in the considered case.

Table 3: BIM tools to achieve innovative value management proposals in the selected case

\begin{tabular}{ll}
$\begin{array}{c}\text { Innovative } \\
\text { Idea }\end{array}$ & $\begin{array}{c}\text { Useful BIM Tools and the applicability to implement the innovative value } \\
\text { management proposal as a successful initiative }\end{array}$ \\
\hline $\begin{array}{l}\text { Passive } \\
\text { Cooling } \\
\text { Techniques }\end{array}$ & $\begin{array}{l}\text { Climate Analysis: determine the passive cooling techniques achieved through } \\
\text { Autodesk, Ecotect, Revit, Vasari, and Green Building Studio. Among the } \\
\text { tools in Ecotect, tools to design shading and carry out solar analysis, thermal } \\
\text { analysis, ventilation and air flow analysis are available to improve the value } \\
\text { achieved through passive cooling. }\end{array}$ \\
& $\begin{array}{l}\text { Wind Pattern of the Area: Flow Design, Vasari/Revit and Site } \boldsymbol{B} \\
\text { Topography. This tool indicates the positioning of site and vegetation around } \\
\text { the area to get a better understanding about the wind patterns. }\end{array}$ \\
& $\begin{array}{l}\text { Simulation CFD: A tool supporting in analysing the wind flow and thermal } \\
\text { simulation capabilities of a designed building. }\end{array}$ \\
& $\begin{array}{l}\text { Thermal loads on the Building: Vasari/Revit and Ecotect have tools for } \\
\text { analysing how heating and cooling loads change throughout the year and what } \\
\text { elements of the design contribute to it the most. (Revit MEP: Heating } \boldsymbol{\&}\end{array}$ \\
Cooling Loads)
\end{tabular}




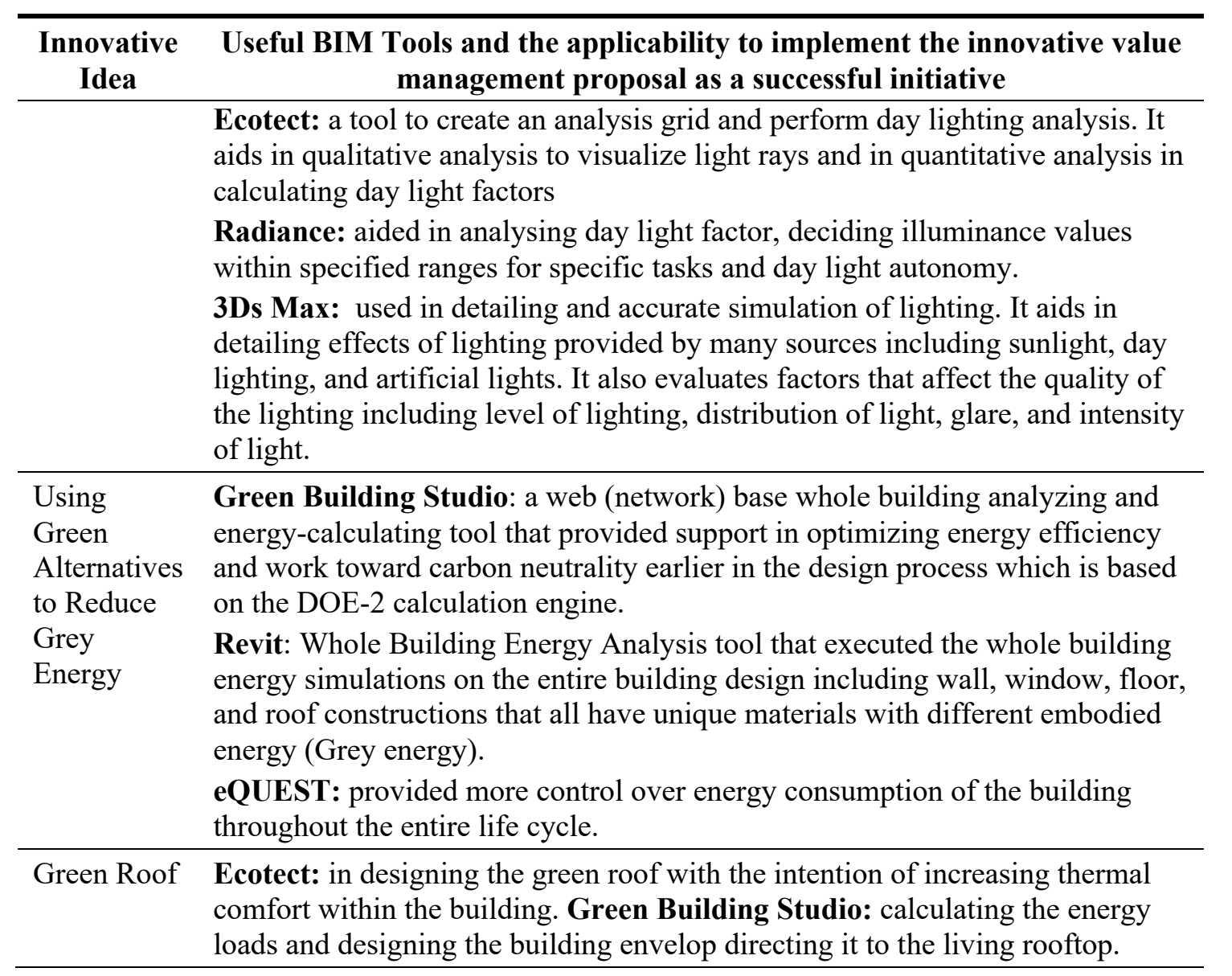

It was a common feature for all of the design ideas suggested and developed in this phase stage to consume a comparatively high capital cost at the initial stage (for construction or installation) but later at the life cycle of the building in operation and maintenance stages to consume less energy and save the operation cost for the systems. These two features of energy conservation and low operation costs combined together enhance the value of the factory building in Thulhiriya while fulfilling certain number of client's requirements. Finally, the developed ideas are combined together to form the final design for the project.

The design development and considering design alternatives has proven to be an effective process when BIM based 3D platform was used. Compared to other phases of value management the development phase was identified as the easiest phase to implement BIM solutions. Green Building Studio and Vasari were the main two solutions that were used in the selected case.

\subsubsection{Presentation Phase}

In the presentation stage, the design team had presented the final design building to the Client. The finalized design included all the ideas generated during brainstorming session and developed during development stage. The developed 3D model with Revit and the simulations done regarding wind loads, day light analysis had been facilitated the Client to obtain a thorough idea about the value management proposal and to continue necessary discussions to do amendments. 


\section{CONCLUSIONS}

The case study result illustrated the possibility to combine BIM together with value management to make the construction process more efficient and accurate. For pre study phase and the information phase of value management, the concepts of EIR of BIM can be implemented to increase the understanding of the overall project scope. This information included cost information, design details, drawings, structural details, and details about project timeline. However, it was observed that a creative phase could not employ BIM solutions since the mind storming sessions were imaginative process of creativeness and experience. The development phase was where BIM solutions were maximally utilized for design development, forecasting rainfall and day light patterns. Further, the comparison of value management proposal was facilitated through the 3D model at the presentation phase. Therefore, this research established the importance of using BIM solutions for value management of construction projects. The study can be extended in the current format to identify different novel BIM solutions to be used for value management success.

\section{REFERENCES}

Arayici, Y., Egbu, C.O. and Coates, S.P., 2012. Building information modelling (BIM) implementation and remote construction projects: issues, challenges, and critiques. Journal of Information Technology in Construction, 17, pp.75-92.

Ashworth, A. and Hogg, K. 2000. Added Value in Design and Construction. Pearson Education, Harlow.

Central Bank of Sri Lanka. 2019. Annual Report of the Monetary Board to the Hon. Minister of Finance for the year 2018 (Vol. 1). Central Bank of Sri Lanka.

Dallas, M.F. 2006. Value and Risk Management: A Guide to Best Practice. Blackwell, Oxford.

Davies, N. 2014. Vibes from Building Boom. Available from http://lmd.lk/construction-industry-2/ [Accessed on 29 June 2016]

Eastman, C., Teicholz, P., Sacks, R. and Liston, K. 2011. BIM Handbook: A Guide to Building Information Modelling for Owners, Managers, Designers, Engineers, and Contractors. Wiley: Hoboken, NJ.

Ellis, R.C.T., Wood, G.D. and Keel, D.A. 2005. Value management practices of leading UK cost Consultants. Construction Management and Economics, 23(5), pp.483-93.

Jaapar, A., Endut, I.R., Bari, N.A.A. and Takim, R., 2009. The impact of value management implementation in Malaysia. Journal of Sustainable Development, 2(2), pp.210-219.

Kelly, J., Male, S., and Graham, D. 2016. Value Management of Construction Projects. (pp. 1-27). Oxford, UK: Blackwell Science Ltd.

Lin, G. and Shen, Q., 2007. Measuring the performance of value management studies in construction: critical review. Journal of Management in Engineering, 23(1), pp.2-9.

Luo, X., Shen, G., Fan, S., and Xue, X. 2010. A Group Decision Support System for Implementing Value Management Methodology in Construction Briefing. International Journal of Project Management, 29(1), pp.1003-1017.

Perera, S., Hayles, C. S. and Kerlin, S., 2011. An analysis of value management in practice: the case of Northern Ireland's construction industry. Journal of Financial Management of Property and Construction, 16(2), pp.94-110.

Pikas, E., Sacks, R. and Hazzan, O. 2013. Building Information Modeling Education for Construction Engineering and Management. II: Procedures and Implementation Case Study. Journal of Construction, Engineering Management, 139(11), p.05013002.

Rangelova, F. and Traykova, M., 2014. Value Management in Construction Project. First ScientificApplied Conference with International Participation 'Project Management in Construction', University of Architecture. Civil Engineering, and Geodesy.

Rogers, J., Chong, H.Y., Preece, C., Lim, C. C., and Jayasena, H. S., 2015. BIM Development and Trends in Developing Countries: Case Studies. Bentham Science Publishers. 
Saieg, P., Sotelino, E. D., Nascimento, D., and Caiado, R. G. G., 2018. Interactions of Building Information Modelling, Lean and Sustainability on the Architectural, Engineering and Construction industry: A systematic review. Journal of Cleaner Production, 174, pp.788-806.

Salvatierra-Garrido, J. and Pasquire, C., 2011. Value theory in lean construction. Journal of Financial Management of Property and Construction, 16(1), pp.8-18.

Shen, Q. and Liu, G., 2004. Applications of value management in the construction industry in China. Engineering, Construction and Architectural Management, 11(1), pp.9-19.

Spaulding, W. M., Bridge, A. and Skitmore, M., 2005. The use of function analysis as basis of value, management in the Australian construction industry. Construction Management and Economics, 23(7), pp.723-732.

Succar, B. 2010, Building Information Modeling maturity matrix, in Underwood, J. and Isikdag, U. (Eds), Handbook of Research on Building Information Modeling and Construction Informatics: Concepts and Technologies, Information Science Publishing, Hershey, PA, pp.65-103.

Succar, B., 2010. Building information modelling maturity matrix. In Handbook of research on building information modeling and construction informatics: Concepts and technologies (pp.65-103). IGI Global.

Thiry, M., 2002. Combining value and project management into an effective programme management model. International Journal of Project Management, 20, pp.221-227.

Welle, B., Haymaker, J. and Rogers, Z., 2011. Thermal Opt: A methodology for automated BIM-based multidisciplinary thermal simulation for use in optimization environments. Building Simulation, 4(4), pp.293-313. 